\author{
Sulistiyo $^{1} \mathbb{D}$, Agus Kristiyanto ${ }^{2}$, , Sapta Kunta Purnama $^{3}(\mathbb{D}$ \\ Sebelas Maret University, Surakarta, Indonesia
}

\title{
The guidance and sports development achievements in Sragen Regency based local excellence
}

\begin{abstract}
This research attempts to find out the government Sragen Regency on implementing Law No. 3 in 2005 chapter 34 about the district/city government is obliged to manage at least one superior sports national and/or international standard. This research using the methodology descriptive qualitative. Research data sources such as 2 employees DISPORA, 2 employees KONI Sragen Regency, 2 athletes and 2 coach. Data collection techniques using interviews. Data analysis techniques use descriptive analysis. Based on the results of research can be concluded as follows: (1) the district government Sragen not implement Law No. 3 in 2005 Chapter 34, (2) KONI not focus on 1 superior sports, KONI focusing on the main tasks KONI to improve performance, (3) Executive power in increasing the achievement is coach, (4) Funding from KONI $85 \%$ directed to the development of sport and DISPORA direct funding for sports competition, (5) Infrastructures in condition enabling, (6) Coaching done through P3B program (Nursery Sustainable Development Program) and Prosukma (Gold Sukowati Program).
\end{abstract}

Keywords: sport development, local excellence

\section{Introduction}

Constitution of the Republic of Indonesia Number 3 In 2005 regarding National Sport System is harmony of a whole subsystem sport in the related planned, integrated, and sustainability to achieve the purpose of national sport. Subsystem referred to include sports actors, sports organizations, sports funding, sport infrastructure, the role of the community, and supporting sport including science, technology, information, and sports industry. Article 34 paragraph 1 explained that the district government/city implement planning, coaching, development, the application of standardization, and raising sport resources based local excellence. In paragraph 2 explained that the district government/city are required to manage at least one superior sports national standard and/or international. Local government, in this case the provincial government/district/city, it is time start more attention to and arrange in a planned, systematic, and manage professionally every form of the sport. Sports an integral part of the form of leisure individual, that an opportunity for competitive activity, and within any limit development also the part that is sustainable from culture of society (Sekot, 2017: 28).

A strategy to create sports organizations that on institutional to regulate sports system which exist at any region i.e. the Department of Youth and Sports shall contain the

\footnotetext{
${ }^{1}$ Sulistiyo, e-mail: f.sulispenjas@ student.uns.ac.id, ORCID: 0000-0002-7299-4863

${ }^{2}$ Agus Kristiyanto, e-mail: aguskriss@yahoo.co.id, ORCID: 0000-0001-7961-4643

${ }^{3}$ Sapta Kunta Purnama, e-mail: saptakunta@yahoo.com, ORCID: 0000-0001-7198-1385
} 
role of the community, professional, partnership, transparency and accountability. Coaching management systems and sports development in the concept of sports management i.e. sporting events, including also physical education containing a mission to achieve educational objectives need better management. Arrangement strategy optimal very important for determining success or failure performance (Whitehead, et al., 2018: 95).

A sport that flourished in Sragen regency composed of different sorts of sports both sports games, martial, athletics, swimming, weightlifting and etc. The development of all sports compared to the development of sport in other districts are still far behind. Seeing the fact, and to improve the quality and achievements of sports in Sragen is the responsibility of all parties. Based on observation, coaching and sports development in Sragen regency still face a number of problems desire politics governors Sragen regency that not optimal in sport, coaching sports who have not directed, the quality of human resources in the field of sports weak, the role of an institution of higher education sports not yet optimal, the role of institutions or the field of research and development of a sport that is still weak, sports infrastructure a limited, the use of sports facilities a limited, understanding and application of physical education and sports it is not clear. In addition, the funds allocated also not maximum because focused on infrastructure Sragen regency. Therefore, researchers research feasibility the government Sragen regency in implementation Law No. 3 in 2005 Chapter 34. The purpose of this research is to know the government in Sragen regency on implementing Law No. 3 in 2005 Chapter 34.

\section{Methods}

Research methods used is descriptive qualitative. Sparkes and Smith (2014: 30) said the qualitative study is a form of social investigation focusing on the manner of someone interpret and make sense of their experience in the world in which they live. According to Nassaji (2015: 130), approach descriptive focus on explain what happened. The data research i.e. 1 employees DISPORA Sragen, 2 employees KONI Sragen, 2 athletes and 2 coach. Data collection is done through observation, interviews and documentation. An instrument interview form guidelines interview. Data analysis done with descriptive analysis.

\section{Results}

A. Coaching and Sports Development

Coaching is a relationship designed in such a way to improve the learning process, effectiveness and meet the needs of a lifetime (Stevens, 2008: 6). Coaching is an effort, action, and activities in efficiently and success to obtain better results. Exercise intensively not enough to ensure that the achievement, this is because improve achievement be achieved if intensive, exercises are performed in quality (Tohar, 2002: 10). The need for stage coaching to produce achievement sports high, is through massive, seedling and achievement stage (Irianto, 2002: 27). 


\section{B. Sports Development}

In principle sports development in the community is based on three orientation, i.e. sport as recreation, sport as health, sport for achievement, and sport for education. The development of the involvement of a specialist coach, especially on extracurricular activities and club, together with increasing intensity and strong public relations with trainer or coach that flourish with local club and a unit of sports development another to increasing the opportunities available for someone to participate in sports, it is also considered a positive impact that inflicted by sports development program (Bloyce and Smith, 2010: 70). To perform sporting events need sports facilities whether it is sports infrastructure in supporting coaching and sports development. Without the sports facilities adequate certainly would be hard to expects the participation of the people in doing sports, kind described by Mutohir dan Maksum (2007: 7) that the more sports facilities available, easier people use it to sporting events.

\section{Local Excellence}

Local excellence is all things that are characteristic regional which includes the economic, culture, information technology and communication, ecology, sport aspect, etc. Local excellence is the result of the earth, creation of art, tradition, culture, service, natural resources, human resources or other excellence an the region (Dwitagama, 2007: 9). Local excellence must be developed from regional potential. The potential of the region is the potential of resource specific a the region. The government and local communities can do a number of efforts and programs, that the potential to be appointed as the region local excellence, so region economy and surrounding can develop well. The quality of the process and realization local excellence is very influenced by resources available, i.e. man, money, machine, material, method, and marketing (Harsuki, 2012: 182). If resources necessary be met, so processes and realization would give a good results, and conversely if resources necessary cannot be met, so processes and the realization will not give good results.

\section{Descriptive Data}

The local government does not focused on one sport but all sports that have the potential to achievement. There are 21 sport is in Sragen regency being included in the event Porprov Central Java XV. Problem that happens among others:

1) The KONI Sragen Regency

a) Have not the creation of culture orderly organization, some sports had been out of term and not/has not done reorganization.

b) Not all sports having exercise program and coaching athletes routinely.

c) A lack of facilities must be provided and some sports equipment damaged.

d) The transfer of management authority High School/equal by the province Central Java, so districts are not many have a chance intervene policy the sports coaching for their students.

2) The DISPORA Sragen Regency

a) Information facilities incomplete.

b) Human resources not yet optimal.

c) Lack of funds for the activity of sports productive. 
d) The absence of a continuation coahing athletes, so that athletes who performed well tending to out of the region.

e) The low a bonus athletes who performed.

f) The lack of adequate infrastructure.

g) The limited nursery pattern, coaching and scouting talent athletes.

h) A less than optimal awareness, empowerment and developing organizations in sports.

\section{Discussion}

Law No. 3 In 2005 regarding National Sport System (SKN). National sport aimed at to maintain and improve health and fitness, achievement, quality of people, Imparting value moral and noble moral, sportsmanship, discipline, strengthen and build unity and nation unity, upholding national security, and raised dignity and honor nations. In chapter $34 \mathrm{Law}$ regarding National Sport System set the district/city government to implement planning, coaching, development, the application of standardization and raising sport resources based local excellence and manage at least one superior sports national and/or international level.

1) Response an Athlete and Coach

Response be important role in running an public policy. In the context of this law, a policy more focused on how far the response an athlete and coach related the implementation of government policy. Statement athletes and coach that in Sragen no superior sports.

2) Usefulness of Law No. 3 in 2005 Chapter 34 By The Athletes and Coaches Benefit if the implementation of Law related superior sports will can be perceived athlete and coach in progress sports in Sragen regency. Local government can make the planning, coaching and raising sport resources early, so that the creation of the development of sport in an region that has moved forward and the creation of an athletes who performed well. In addition, each region will introduce the sport that can be seeded as typical excellence local region.

3) The Implementation of Law No. 3 in 2005 Chapter 34

KONI and DISPORA is actors on the implementation of Law No. 3 In 2005 Chapter 34. In fact, local governments can't implement the law because the government focus on the main tasks to improve their performance so as not focused on one sport.

The success of parameters region sport generally is measured by achievements in the championship every sport. The implementation of Porprov became one of the size of which the position of a district can gain achievements maximally. Sragen regency follow 21 sport by 78 number the match in the event Porprov XV in 2018. The sport is Tarung Derajat (Kodrat), Archery, Petanque, Football, Indoor Volleyball, Beach Volleyball, Silat, Karate, Gymnastics, Boxing, Wushu, Motor Racing, Rock Climbing, Futsal, Swimming, Yong Moo Do, Cycling, Chess, Tae Kwon Do, Athletics, and Badminton. From 21 sports, a sport that superior win gold in the event Porprov in 2018 i.e. Petanque, which petanque achieve 3 gold medals.

An achievement sports are not purely can be obtained or come alone, this is the process of coaching started in an early age. Therefore, required sports management to set the achievement sports. Sports management is the whole process of activities in sports 
with is using all available resources and managed to achieve a purpose sports achievement. Resources in the context of sports management form man, money, materials and methods. The success of a program determined by the quality of human resources who do it. Human resources skilled means can be able to do duty and responsibilities well and correctly. As maker planning or program, KONI not always were directly involved in coaching activities. The reality in field, needed coach as an executor the program. Money is a fee has been allocated and used to implement a program. The use of money from government in Sragen regency allocated to a sports event. KONI use funds to give award on an athlete who performed well in regional and provincial competition. DISPORA also allocated funds to a sports event.

In improving sports achievement maximally needed infrastructures. In the broad, infrastructures owned Sragen regency inadequate. There are 3 units pingpong table (table tennis), 12 units bat table tennis, 12 units ball table tennis, 116 units ball volleyball, 58 net volleyball, 12 units racket, 3 units net badminton, 2 units ball football, and 1 unit net goal football. Local government are required to conduct coaching and sports development in accordance with the authority and responsibilities. In fact, KONI still tried to develop sports achievement in Sragen regency through Sustainable Coaching Nursery Program (P3B) and coaching. Coaching directed through exercise adapted to growth and development athlete. In Sragen regency, implementation coaching done with Prosukma program (Gold Sukowati Program) and given directly to each sport.

Sport is part of process and achievement objective the national development, so existence and role of sport in the social life, national and state must be placed on a clear position in the system national law. Policy in Law No. 3 In 2005 Chapter 34 is a legal basis on the implementation superior sports in the region. The law can create conditions conducive for regional sports, such as system sports organizations who organized and regular cleanly, the availability of minimal standards on sports infrastructure, the availability of sports actors quality with the numbers of adequate, the availability of a sport that seeded.

\section{Conclusion}

Based on research result and results analysis the data that has been done, can be obtained a conclusion as follows:

1) Implementation Of Law No. 3 In 2005 Chapter 34 could not be implemented in Sragen Regency.

2) In reality, the KONI are not in focus on 1 superior sports. KONI focus on main task of KONI to improve their performance. In Sragen there are 21 sports which are prioritized in Porprov in 2022.

3) Executive staff the most important in increasing achievement is coach.

4) Funding from KONI $85 \%$ directed for sports development. DISPORA direct funding for sports competition.

5) KONI is irresponsible in a problem of infrastructures. Infrastructures available is 3 units pingpong table (table tennis), 12 units bat table tennis, 12 units ball table tennis, 116 units ball volleyball, 58 net volleyball, 12 units racket, 3 units net badminton, 2 units ball football, and 1 unit net goal football.

6) Coaching done through P3B program (Sustainable Coacing Nursery Program) and Prosukma (Gold Sukowati Program). 


\section{References}

Bloyce, D., and Smith, A. 2010. Sport Policy and Development: An Introduction. London and New York: Routledge Taylor \& Francis Group.

Dwitagama, D. 2007. Penyusunan Model Kurikulum Keunggulan Lokal. Jakarta: Pusat Kurikulum Balitbang Depdiknas.

Harsuki. 2012. Pengantar Manajemen Olahraga. Jakarta: Rajawali Pers.

Irianto, D.P. 2002. Dasar-Dasar Kepelatihan. Yogyakarta: FIK UNY.

Mutohir, T.C., dan Maksum, A. 2007. Sport Development Indeks. Jakarta: PT. Indeks.

Nassaji, H. 2015. Qualitative and Descriptive Research: Data Type Versus Data Analysis. Language Teaching Research 2015, Vol. 19(2) 129-132. DOI: 10.1177/1362168815572747.

Sekot, A. 2017. Sociological Perspective Of Sport. The Spark, Vol.2, Issue 1, 2017: 2844.

Sparkes, A.C., and Smith, B. 2014. Qualitative Research Methods In Sport, Exercise And Health From Process To Product. London and New York: Routledge Taylor \& Francis Group. 